\title{
Research Paper: Effectiveness of Group Hope Therapy on the Psychological Indicators in Women With Addicted Husbands
}

\author{
Anahita Khodabakhshi-Koolaee ${ }^{1}$, Leili Mosalanejad ${ }^{2 *}$, Morteza Gholami ${ }^{3}$, Omid Massah ${ }^{4}$ \\ 1. Department of Psychology and Educational Sciences, Faculty of Humanities, Khatam University, Tehran, Iran \\ 2. Social Determinants of Health Research Center, Jahrom University of Medical Sciences, Jahrom, Iran. \\ 3. Department of Language, School of Medicine, Jahrom University of Medical Sciences, Jahrom, Iran. \\ 4. Substance Abuse and Dependence Research Center, University of Social Welfare \& Rehabilitation Sciences, Tehran, Iran
}

Article info:

Received: 14 Sep. 2016

Accepted: 07 Dec. 2016

Citation: Khodabakhshi-Koolaee A, Mosalanejad L, Gholami M, Massah O. Effectiveness of Group Hope Therapy on the Psychological Indicators in Women With Addicted Husbands. Iranian Rehabilitation Journal. 2017; 15(1):15-22. https://doi. org/10.18869/nrip.irj.15.1.15

https://doi.org/10.18869/nrip.irj.15.1.15

Keywords:

Hope, Meaning of life, Addiction, Orientation of purpose, Group therapy

\section{ABSTRACT}

Objectives: Hope therapy is one of the psychological interventions to help the couples deal with addiction problem. The aim of this study was to evaluate the effectiveness of the hope therapy on the orientation of the purpose and meaning of life expectancy in women with addicted husbands.

Methods: This was a quasi-experimental study with pretest, posttest control group. The population of this study included all wives of male addicted patients who referred to drug rehabilitation institutions in Tehran to treat their husbands' addiction in 2014. The sample size was 30 people. Convenience samplings were carried out to collect data. Data gathering were done by MLQ (Meaning of Life Questionnaire) and AGQ -Achievement Goal Questionnaire (goal orientation)- and analyzed by ANCOVA through SPSS software version 20.

Results: The findings showed that hope therapy increased the orientation of purpose and meaning of life scores in experimental group $(\mathrm{P}<0.001)$. While, these changes were not observed in control group.

Discussion: The results revealed that the hope therapy intervention could raise the psychological positive elements like goal setting and the meaning of life among wives of male addicted patients. Rehabilitation counselors and psychologists could apply these interventions to reduce the burden and disturbance of those who live with their addicted couples.

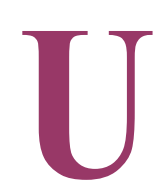

\section{Introduction}

ndoubtedly, nowadays, addiction is one of the factors that undermines the foun- dation of the family and makes family problems. The condition is deteriorated when the wives of the addicted people get aware of their husbands' conditions. In such circumstances, the wives of the addicts lose their hope

* Corresponding Author:

Leili Mosalanejad, PhD

Address: Social Determinants of Health Research Center, Jahrom University of Medical Sciences, Jahrom, Iran.

Tel: +98 (917) 7920813

E-mail: saedparsa2012@gmail.com 
of life, their psychological well-beings are subject to disturbances, social relations and the quality of life are impaired and sadness, grief, loneliness, shame and lack of psychological security would dominate their lives [1].

Among psychological treatments, the Snyder hope therapy is the only treatment which considers hope as the main goal of treatment. Snyder, the founder of the hope-base treatment theory defines hope as a structure containing two concepts: The ability to design passes toward desired goals despite obstacles or motivating factor for using these passes [2]. Hope therapy is a solutionfocus therapy and treatment of a story or narrative [3].

Psychologists have embraced that hope, like goal and optimism, can have an effect on the physical and mental diseases [4]. Hope therapy based on positive psychological approach considers the person's ability instead of focusing solely on human weaknesses [5-7]. From Snyder's view, boredom and frustration are related with the lack of goal realization which eclipses the person's meaning of life [8-12].

In fact, hope therapy is a treatment plan designed to enhance hopeful thinking and strengthen activities related to following goals. In this treatment, the participants learn how to (a) determine the important, achievable, and measurable goals, (b) determine multiple pathways to move towards these goals (c) identify the sources of motivation and interaction of each obstacle on motivation (d) review progress toward the goal, and (e) modify goals and pathways, if necessary [13-15].

Researchers have found that group consultation through hope therapy has high efficacy in determining goals. When a person sets a goal for himself so that it is worth to try hard to reach it, life turns much more meaningful to him. All of these factors are useful in order to promote mental health and psychological well-being [15, 16]. Various studies have shown that hope is directly related to positive goals [17]. Hope therapy, either individually or in group, has promoted the meaning of life, and has significantly improved the treatment of disease. In the study of some researchers on hope-base interventions on adults with depression, it has been shown that this treatment leads to depression and anxiety reduction, increase self-esteem and increases hope [18-20].

Setting goal in life is one of the axis that seems to have changed with hope therapy and hope-base intervention. In fact, the goal-setting theory emphasizes the fact that purposeful people work efficiently than undetermined ones and people with challenging goals perform better than those with easy goals [21].
"Meaning of life" is also one of the most important philosophical, psychological, and religious issues in the modern and the industrialization era of societies and all-round development of science and technology [22]. Meaning of life and its place for being happy are irrefutable and undeniable. Several research findings have shown that meaning of life is an essential element in the psychological-emotional well-being and is systematically associated with different aspects of personality, physical and mental health, stress adaptation, religion and religious activities and behavioral disorders. [23-25].

In the studies recently conducted, no specific study has been carried out in this field generally, and in Iranian society in particular, to assess the orientation of the purpose and meaning of life in women with addicted husbands and the effectiveness of group hope therapy. Therefore, the aim of this study is to answer the question of what the effects of group hope therapy and life orientation are in women with addicted husbands.

\section{Methods}

The present research was a quasi-experimental study with pre-test post-test and control group. The population of this study included all wives of male addicted patients who referred to drug rehabilitation institutions in Tehran to treat their husbands' addiction in 2014. The sample size was 30 people and convenience samplings were applied to analyze the data.

Sampling was carried out in such a way that those clients who had addicted husbands and referred to clinic for treatment and consultation were given the questionnaires of goal orientation and meaning of life. 30 with low scores were chosen. Fifteen were assigned voluntarily in control group and 15 in experimental group. To carry out quasiexperimental research, we needed at least 12 participants in each groups, therefore, researchers selected 13 participants for present study. The experimental group received eight sessions of hope therapy. The researcher held three sessions of training for three days for the control group after the end of the study for ethical considerations. In this study, the Fraser, Steger, Oishi and Kaller (2006) questionnaire of meaning of life, and goal orientation questionnaire of Elliot and McGregor (2011) were used.

Meaning of Life Questionnaire (Steger, Frasier, Oishi and Kaller)

The scale of meaning of life by Fraser, Steger, Oishi, and Kaller (2006) were offered to assess the meaning of life and try to find it. Validity, reliability, and factor struc- 
Table 1. The content of the meetings is as follows:

\begin{tabular}{|c|c|c|c|}
\hline Session & Topic & Objective & Method \\
\hline 1 & $\begin{array}{l}\text { Introduction expressing work } \\
\text { and group regulations }\end{array}$ & $\begin{array}{l}\text { Making communication and training for } \\
\text { listening well }\end{array}$ & $\begin{array}{l}\text { Using mutual introduction and discussion } \\
\text { method }\end{array}$ \\
\hline 2 & Introducing the basics of hope & Review of the fundamentals of hope in life & $\begin{array}{l}\text { Irrational beliefs, using encouraging state- } \\
\text { ments and homework }\end{array}$ \\
\hline 3 & Finding hope in people & $\begin{array}{l}\text { Helping mothers to understand the ele- } \\
\text { ments of hope }\end{array}$ & $\begin{array}{l}\text { Interviews based on Hope and writing } \\
\text { samples of your life }\end{array}$ \\
\hline 4 & Hope increasing & Creating ways to solve the problems & Using life story methods \\
\hline 5 & $\begin{array}{l}\text { Strengthening and building } \\
\text { strength }\end{array}$ & $\begin{array}{l}\text { Determining promising therapeutically } \\
\text { objectives }\end{array}$ & Learning goal setting of Seligman \\
\hline 6 & Determination power & Dos and taboos & Techniques of searching for stories of hope \\
\hline 7 & Reassuring to fix problems & Maintaining hope in mothers & Application of knowledge cycle \\
\hline 8 & Finalizing hope training & Summarizing and reviewing lessons & Homework writing positive self-talk \\
\hline
\end{tabular}

Ilranian Rehabilitation Journal

ture of the questionnaires had been examined in different studies with different samples. The scale of meaning of life consists of two subscales that evaluates the meaning of life and seeks to find the meaning. According to the study of Steger et al (2006), the reliability of subscales was 0.70 and 0.73 respectively [26].

\section{Goal Orientation Questionnaire (Elliott and McGregor)}

Questionnaire to measure the dimension of goal orientation was prepared on four-dimensional model by Elliot and McGregor and consisted of 12 items, so that every three items measures an orientation and each item is a 7-part on Likert scale. Using factor analysis, Elliot and McGregor (2001) extracted four factors which explored $81.5 \%$ of the total variance [27]. Both questionnaires are used in Iran and many researchers reported reliability and validity of them [28-30]. proposal extracted from paper approved in ethical committee. Ethical consideration was considered by using questionnaires and group therapy in people.

\section{Interventions sessions}

In this treatment, the participants first learn the basics of the theory of hope and then they were taught how to apply these principles in their lives [31, 32] (Table 1). Finalizing the interventions sessions, the participants responded to the questionnaires again after one week. To consider the ethical research codes, the interventions were implemented to the control group after the end of research.

\section{Data analysis}

Descriptive and inferential statistical methods were used for statistical analysis. Methods such as mean, standard deviation, frequency and percentage were used for descriptive statistics. To analyze the hypothesis, ANCOVA was used and then based on the significance level (sig), hypotheses were examined. SPSS software version 20 was used to analyze results.

The followings were taken into consideration as moral criteria used in this study: Avoiding making subjects participate in the research, conducting three sessions of group therapy for the control group after completion of the research, and commitment to confidentiality of the participants' data.

\section{Results}

Given the information in the Table 2, in the experimental group, most of the participants $(46.66 \%)$ were between the ages 31 to 35 years and the lowest $(6.66 \%)$ were between the ages of 41 to 45 years. In the control group, most of the participants $(33.33 \%)$ were between ages 25 to 35 years and the lowest $(6.66 \%)$ were between the ages of 41 to 45 years. The average ages of the experimental group and the control group were 34.73 and 33.86 respectively (Table 2 ).

All variables of orientation of purpose and meaning of life had significant increase in post-test in experimental group, but in the control group, this change does not seem much significant despite an increase in post-test (Table 3 ).

The results of the Table 4 show that by adjusting the pre-test scores, there is a significant effect among participants $(\mathrm{P}<0.05)$. It can be said that group hope therapy is effective in women with addicted husbands on the orientation of the purpose and meaning of life (Table 4). 
Table 2. Demographic characteristics of samples by age and group

\begin{tabular}{|c|c|c|c|c|}
\hline & \multicolumn{2}{|c|}{ Experimental } & \multicolumn{2}{|c|}{ Control } \\
\hline & Frequency & Percentage & Frequency & Percentage \\
\hline $25-30$ & 2 & 13.33 & 5 & 33.33 \\
\hline $31-35$ & 7 & 46.66 & 5 & 33.33 \\
\hline $36-40$ & 5 & 33.33 & 4 & 26.66 \\
\hline $41-45$ & 1 & 6.66 & 1 & 6.66 \\
\hline Total & 15 & 100 & 15 & 100 \\
\hline Mean & \multicolumn{2}{|c|}{34.73} & \multicolumn{2}{|c|}{33.86} \\
\hline SD & \multicolumn{2}{|c|}{3.01} & \multicolumn{2}{|c|}{4.80} \\
\hline
\end{tabular}

Also covariance analysis show this difference is 0.924 for orientation and 0.930 for meaning of life (Table 4).

\section{Discussion}

The results indicated that wives of experimental group had higher scores in goal orientation and meaning of life than the other group. These findings were consistent with the results of Kashani et al. [33]. Aladini and Kajbaf reported that the hope therapy results boosted hope and mental health and reduced social dysfunction and depression in depressed women [32]. Hope therapy led to distress reduction with the aim of creating hope in the persons. Because of the goals in life, describing future

Table 3. Descriptive indicators of purpose orientation and meaning of life separately and based on pre-test and post-test experimental and control groups

\begin{tabular}{|c|c|c|c|c|c|}
\hline \multirow{2}{*}{ Group } & \multirow{2}{*}{ Scale } & \multicolumn{2}{|c|}{ Pre-Test } & \multicolumn{2}{|c|}{ Post-Test } \\
\hline & & Mean & SD & Mean & SD \\
\hline \multirow{8}{*}{ Experimental } & Mastery- approach & 4.6 & 1.05 & 10.26 & 1.09 \\
\hline & Mastery-avoiding & 4.4 & 1.05 & 10.13 & 1.18 \\
\hline & Performance-approach & 3.8 & 0.77 & 10.73 & 1.48 \\
\hline & Performance-avoidance & 4.4 & 1.05 & 10.26 & 1.03 \\
\hline & Total & 17.2 & 2.21 & 41.40 & 2.97 \\
\hline & Finding meaning in life & 18.53 & 2.03 & 30.06 & 2.71 \\
\hline & Meaning in life & 20 & 1.25 & 28.46 & 2.74 \\
\hline & Total & 38.53 & 1.55 & 58.53 & 3.02 \\
\hline \multirow{8}{*}{ Control } & Mastery- approach & 4.6 & 1.05 & 4.73 & 1.33 \\
\hline & Mastery-avoidance & 4.4 & 1.05 & 4.46 & 0.915 \\
\hline & Performance-approach & 3.8 & 0.77 & 3.86 & 0.915 \\
\hline & Performance-avoidance & 4.4 & 1.05 & 4.66 & 1.29 \\
\hline & Total & 17.20 & 2.21 & 17.73 & 2.96 \\
\hline & Finding meaning in life & 18.53 & 2.03 & 18.86 & 1.84 \\
\hline & Meaning in life & 20 & 1.25 & 19.86 & 1.3 \\
\hline & Total & 38.53 & 1.55 & 38.73 & 1.38 \\
\hline
\end{tabular}


Table 4. Analysis of covariance of hope therapy effects on the orientation of the purpose and meaning of life

\begin{tabular}{ccccccc}
\hline Variable & Value & df & df & df & Level of Sig & ETA \\
\hline Orientation & 1.24 & 1 & 1.24 & 0.116 & 0.001 & 0.924 \\
\hline Meaning of life & 0.191 & 1 & 0.191 & 0.024 & 0.001 & 0.930 \\
\hline
\end{tabular}

Iranian Rehabilitation Journal

once more and the significance of this life are considered the main concepts of life and increases comfort and energy in people $[34,35]$.

On the other hand, hopefuls take lesson from adverse events instead of focusing on them and use them to pursue future goals [36]. Based on what was mentioned, hopefuls show greater commitment towards mental health, life satisfaction, and greater adaptability in case of encountering challenges and seek help from multiple support sources and consequently, experience less distress and mental challenges [37]. According to Feldman and Snyder, psychologists can consider hope structure as a psychological positive point. They believe this structure can help the development of mental health [38].

Hope consists of two cognitive and emotional components. Cognitive component includes the expecting events to occur in the future and the emotional component considers these events positively which have effective and favorable outcomes. Emotional component can be a predictor of positive events in the future and consequently increases meaning life [39]. Adults, who are benefiting from high levels of hope, look at others as sources of support and reliance [40]. They also believe they can adapt more in case they encounter challenges in their lives, experience greater happiness, and are more satisfied with their lives [41, 42]. To implement the present study, the researchers faced barriers that limited generalizability of the results to other research. These obstacles included first, guidance and coordination of the participants in holding group therapy classes. Second, the measurement tools of the questionnaire are subjective.

\section{Conclusion}

The results revealed that the hope therapy intervention could raise the psychological positive elements like goal setting and the meaning of life among wives of male addicted patients. Rehabilitation counselors and psychologists could apply these interventions to reduce the burden and disturbance of those who live with their addicted couples.

This study had several practical suggestions: first, group therapy sessions were held for families of clients in an attempt to improve their quality of life in the rehab camp. Second, in addition to clients, the wives of clients were also evaluated in clinical trials to be directed in the case of any problem in drug rehabilitation camps. Third, it is suggested that the research topic be carried out in other regions (with different traditions and culture) considering the importance of this group. And forth, it is recommended that further research carry out on the effectiveness of hope therapy with other psychological variables such as self-esteem, self-confidence, stress, etc.

\section{Acknowledgments}

This paper is extracted from a study which was approved and financially supported by Khatam University. The researchers' thanks are due to all the participants and drug rehabilitation institutions in Tehran for their coop-eration and support.

\section{Conflict of Interest}

The authors declared no conflict of interests.

\section{References}

[1] Halford WK. Brief therapy for couples: Helping partners help themselves. New York: Guilford Press; 2003.

[2] Kar A. Positive psychology: The science of happiness and human strengths [P. Sharifi Persian trans.]. Tehran: Sokhan; 2008.

[3] Garcia JAS, Sison KG. Locus of hope and subjective wellbeing. International Journal of Research Studies in Psychology. Consortia Academia Publishing; 2012; 1(3). doi: 10.5861/ ijrsp.2012.297

[4] Kok JK, Goh LY, Gan CC. Meaningful life and happiness: Perspective from Malaysian Youth. The Social Science Journal. 2015; 52(1):69-77. doi: 10.1016/j.soscij.2014.10.002

[5] Yeung DY, Ho SMY, Mak CWY. Brief report: Attention to positive information mediates the relationship between hope and psychosocial well-being of adolescents. Journal of Adolescence. 2015; 42:98-102. doi: 10.1016/j.adolescence.2015.04.004 
[6] Snyder CR, Harris C, Anderson JR, Holleran SA, Irving LM, Sigmon ST, et al. The will and the ways: Development and validation of an individual-differences measure of hope. Journal of Personality and Social Psychology. 1991; 60(4):570-85. doi: $10.1037 / 0022-3514.60 .4 .570$

[7] Butler J, Ciarrochi J. Psychological acceptance and quality of life in the elderly. Quality of Life Research. 2007; 16(4):607-15. doi: 10.1007/s11136-006-9149-1

[8] Snyder CR, Lopez SJ. Handbook of positive psychology. Oxford: Oxford University Press; 2001.

[9] Snyder CR. Conceptualizing, measuring, and nurturing hope. Journal of Counseling \& Development. 1995; 73(3):35560. doi: 10.1002/j.1556-6676.1995.tb01764.x

[10] Snyder CR, Harris C, Anderson JR, Holleran SA, Irving LM, Sigmon ST, et al. The will and the ways: Development and validation of an individual-differences measure of hope. Journal of Personality and Social Psychology. 1991; 60(4):57085. doi: 10.1037/0022-3514.60.4.570

[11] Snyder CR. Hope theory: Rainbows in the mind. Psychological Inquiry. 2002; 13(4):249-75. doi: 10.1207/ s15327965pli1304_01

[12] Snyder CR, Ritschel LA, Rand KL, Berg CJ. Balancing psychological assessments: Including strengths and hope in client reports. Journal of Clinical Psychology. 2005; 62(1):33-46. doi: $10.1002 /$ jclp.20198

[13] Wells M. The effects of gender, age, and anxiety on hope: Differences in the expression of pathways and agency thought [PhD dissertation]. Texas: Texas A \& M UniversityCommerce; 2005.

[14] Hanna D, White R, Lyons K, McParland MJ, Shannon C, Mulholland C. The structure of the Beck Hopelessness Scale: A confirmatory factor analysis in UK students. Personality and Individual Differences. 2011; 51(1):17-22. doi: 10.1016/j. paid.2011.03.001

[15] Schrank B, Stanghellini G, Slade M. Hope in psychiatry: A review of the literature. Acta Psychiatrica Scandinavica. 2008; 118(6):421-33. doi: 10.1111/j.1600-0447.2008.01271.x

[16] Butler J, Ciarrochi J. Psychological acceptance and quality of life in the elderly. Quality of Life Research. 2007; 16(4):60715. doi: 10.1007/s11136-006-9149-1

[17] Snyder CR. Handbook of hope: Theory, measures, and applications. Cambridge: Academic press; 2000.

[18] Bailey TC, Snyder CR. Satisfaction with life and hope: A look at age and marital status. The Psychological Record. 2007; 57(2):233

[19] Hankins SJ. Measuring the efficacy of the Snyder hope theory as an intervention with an inpatient population $[\mathrm{PhD}$ dissertation]. Mississippi: University of Mississippi; 2004.

[20] Scheier MF, Carver CS, Bridges MW. Optimism, pessimism, and psychological well-being: Optimism \& pessimism: implications for theory, research, and practice. American Psychological Association. 2001; 1:189-216. doi: 10.1037/10385009

[21] Cheavens JS, Feldman DB, Gum A, Michael ST, Snyder CR. Hope therapy in a community sample: A pilot investigation.
Social Indicators Research. 2006; 77(1):61-78. doi: 10.1007/ s11205-005-5553-0

[22] Zalta EN, Nodelman U, Allen C, Perry J. Stanford encyclopedia of philosophy. California: Stanford University. 2005.

[23] Metz T. The meaningful and the worthwhile: Clarifying the relationships. The Philosophical Forum. 2012; 43(4):435-48. doi: 10.1111/j.1467-9191.2012.00436.x

[24] Segerstrom SC, Evans DR, Eisenlohr-Moul TA. Optimism and pessimism dimensions in the Life Orientation Test-Revised: Method and meaning. Journal of Research in Personality. 2011; 45(1):126-9. doi: 10.1016/j.jp. 2010.11.007

[25] Ho MY, Cheung FM, Cheung SF. The role of meaning in life and optimism in promoting well-being. Personality and Individual Differences. 2010; 48(5):658-63. doi: 10.1016/j. paid.2010.01.008

[26] Steger MF, Frazier P, Oishi S, Kaler M. The meaning in life questionnaire: Assessing the presence of and search for meaning in life. Journal of Counseling Psychology. 2006; 53(1):8093. doi: $10.1037 / 0022-0167.53 .1 .80$

[27] Elliot AJ, McGregor HA. A $2 \times 2$ achievement goal framework. Journal of Personality and Social Psychology. 2001; 80(3):501-19. doi: 10.1037/0022-3514.80.3.501

[28] Mesrabadi J, Jafariyan S, Ostovar N. [Discriminative and construct validity of meaning in life questionnaire for Iranian students (Persian)]. International Journal of Behavioral Sciences. 2013 Apr 1; 7(1):83-90.

[29] Khormaei F, Khayyer M. [Relationship of goal orientations with approach to learning among university students (Persian)]. Journal of Psychology. 2007; 2(7):123-138.

[30] Davari M, Gholamali Lavasani M, Ejei J. [Relationship between perfectionism and academic self-efficacy with students achievement goals (Persian)]. Journal of Psychology. 2012; 16(3): 266-81

[31] Snyder CR. Teaching: The lessons of hope. Journal of Social and Clinical Psychology. 2005; 24(1):72-84. doi: 10.1521/ jscp.24.1.72.59169

[32] Alaeddini Z, Kajbaf MB, Molavi H. [The effects of group hope-therapy on mental health of female students in Isfahan university (Persian)].Research in Psychological Health. 2008; 1(4):66-76.

[33] Lotfi Kashani F, Vaziri Sh, Akbari ME, Zeynolabedini N, Sanaei H, Jamshidifar Z. The effectiveness of creating hope on distress of women with breast cancer. Procedia-Social and Behavioral Sciences. 2014; 159:201-5. doi: 10.1016/j.sbspro.2014.12.357

[34] Khodabakhshi Koolaee A, Derakhshandeh M. [Effectiveness of hope-oriented group therapy on life meaning and resilience in mothers with physical-motor disabled children (Persian)]. Iranian Journal of Pediatric Nursing. 2015; 1(3):1525.

[35] Kalani N, Mosalanejad L, Abdolahifard S. [The effect of group hope therapy integrated with mobile learning on hope and perceived stress levels in MS patients (Persian)]. Biosciences, Biotechnology Research Asia. 2015; 12(3):1947-55. doi: $10.13005 /$ bbra/1861 
[36] Yanos PT, Roe D, Lysaker PH. The impact of illness identity on recovery from severe mental illness. American Journal of Psychiatric Rehabilitation. 2010; 13(2):73-93. doi: $10.1080 / 15487761003756860$

[37] Sulkers E, Fleer J, Brinksma A, Roodbol PF, Kamps WA, Tissing WJE, et al. Dispositional optimism in adolescents with cancer: Differential associations of optimism and pessimism with positive and negative aspects of well-being. British Journal of Health Psychology. 2012; 18(3):474-89. doi: 10.1111/j.2044-8287.2012.02096.x

[38] Feldman DB, Snyder CR. Hope and the meaningful life: Theoretical and empirical associations between goal-directed thinking and life meaning. Journal of Social and Clinical Psychology. 2005; 24(3):401-21. doi: 10.1521/jscp.24.3.401.65616

[39] King LA, Hicks JA, Krull JL, Del Gaiso AK. Positive affect and the experience of meaning in life. Journal of Personality and Social Psychology. 2006; 90(1):179-96. doi: 10.1037/00223514.90.1.179

[40] Kavradim ST, Özer ZC, Bozcuk H. Hope in people with cancer: A multivariate analysis from Turkey. Journal of Advanced Nursing. 2012; 69(5):1183-96. doi: 10.1111/j.13652648.2012.06110.x

[41] Marques SC, Lopez SJ, Mitchell J. The role of hope, spirituality and religious practice in adolescents' life satisfaction: Longitudinal findings. Journal of Happiness Studies. 2012; 14(1):251-61. doi: 10.1007/s10902-012-9329-3

[42] Marques SC, Pais-Ribeiro JL, Lopez SJ. The role of positive psychology constructs in predicting mental health and academic achievement in children and adolescents: A twoyear longitudinal study. Journal of Happiness Studies. 2011; 12(6):1049-62. doi: 10.1007/s10902-010-9244-4 
